\title{
The impact of supply pressure on gas injector expenditure characteristics
}

\begin{abstract}
The paper analyzes the changes in an LPG injector flow mass characteristics when input pressure is altered. The research was carried out at a test stand with an air-supplied injector. The test results (the pressure both before and behind an injector, a control signal and the current flowing through an electromagnetic coil) were analyzed for the impact of pressure on the injector characteristics. The analysis deals with a pressure effect on a unit mass flow, injector opening dead time (minimum time of a signal that causes an opening), the characteristics linearity, and its intersection point with a time axis. There was also analyzed a single injection time course, particularly emphasizing injector valve opening and closing time. It has been stated that the increase in pressure results in the increased unit mass flow and the simultaneous increase in injector dead time as well as a shift of the intersection point with a time axis along this axis.
\end{abstract}

Key words: injector, $L P G$, test bed research, characteristic

\section{Wpływ ciśnienia zasilania na charakterystykę wydatku wtryskiwacza gazu}

\begin{abstract}
W artykule przedstawiono analize zmiany charakterystyki wydatku trzpieniowego wtryskiwacza gazu LPG przy zmianie ciśnienia zasilania. Badania przeprowadzono na stanowisku badawczym przy zasilaniu wtryskiwacza powietrzem. Przeanalizowano wyniki pomiarów ciśnienie przed i za wtryskiwaczem, sygnał sterowania oraz prądu przepływający przez cewkę, pod kątem wpływu ciśnienia na charakterystykę wtryskiwacza. Analiza objęła wplyw na wydatek jednostkowy, martwy czas otwarcia wtryskiwacza, liniowości charakterystyki oraz punku jej przecięcia z osią czasu. Przeanalizowano także przebieg pojedynczego wtrysku ze szczególnym naciskiem na czas otwarcia i zamknięcia zaworu wtryskiwacza. Wykazano, że wzrost ciśnienia powoduje zwiększenie wydatku jednostkowego przy jednoczesnym zwiększeniu martwego czasu wtryskiwacza oraz przesunięcie punktu przecięcia z osią czasu wzdluż osi czasu.
\end{abstract}

Słowa kluczowe: wtryskiwacz, LPG, badania stanowiskowe, charakterystyka

\section{Introduction}

Internal combustion engines fuelled by gaseous fuels (LPG or CNG) need to satisfy the same environmental requirements as petrol-fueled engines [6]. This implies a very precise quality control of an air-fuel mixture and thus the quantity of gas supplied. To obtain such accuracy, two conditions need to be fulfilled. The first one refers to a suitable supplying device, i.e. a gas injector; whereas the second, a proper system construction $[3,4]$ and the calibration of a control algorithm that calculates petrol injection time against gas injection time $[2,5]$. The calibration of such an algorithm, by contrast, requires the knowledge of gas injector characteristics and its variability throughout the whole of system operation.

Gas injectors differ significantly from petrol ones, mainly in the size of a fuel outflow pipe. This is due to the change in working medium states, and therefore a substantial increase in the volumetric mass flow of a gaseous fuel as compared to that of a liquid fuel. This change involves certain phenomena that do not occur inside liquid-fuel based injectors. These phenomena are related to working medium compressibility and affect a fuel dosage process. The analysis of these phenomena are given in $[1,7]$ and show that the change of a working medium state makes flow stabilization time longer after an injector valve opens. This has a direct impact on an injector mass flow characteristics.

Simultaneously, most of sequential gas injection systems work with regulators where gas pressure is set as fixed

\section{Wprowadzenie}

Wymagania ekologiczne stawiane silnikom spalinowym zasilanym paliwem gazowym (LPG lub CNG) wymuszają spełnienie przez nie takich samych wymagań jak w przypadku silników zasilanych benzyną [6]. Oznacza to konieczność bardzo dokładnego sterowania jakością mieszanki paliwowo-powietrznej, a zatem ilością podawanego gazu. Aby uzyskać taką dokładność konieczne spełnienie dwóch warunków. Pierwszym jest zastosowanie odpowiedniego urządzenia wykonawczego jakim jest wtryskiwacz gazu. Drugim natomiast jest prawidłowe zabudowanie układu [3, 4] i kalibracja algorytmu sterującego, przeliczającego czasu wtrysku benzyny na czas wtrysku gazu $[2,5]$. Kalibracja algorytmu wymaga natomiast znajomość charakterystyki wtryskiwacza gazowego wraz z jej zmiennością w całym zakresie pracy układu.

Wtryskiwacze gazu różnią się znacząco od wtryskiwaczy benzyny przede wszystkich wielkością kanału wypływu paliwa. Wynika to ze zmiany stanu skupienia czynnika roboczego, a zatem ze znacznego zwiększenie objętościowego wydatku paliwa gazowego w stosunku do paliwa płynnego. Zmiana ta pociąga za sobą pojawienie się zjawisk nie występujących wewnątrz wtryskiwaczy paliwa płynnego. Zjawiska te związane są ze ściśliwością czynnika roboczego i wpływają na przebieg procesu podawania paliwa. Analizy tych zjawisk przedstawiono w pracach $[1,7]$ wykazując, że zmiana stanu skupienia czynnika roboczego wpływa na wydłużenie czasu stabilizacji przepływu po otwarciu zaworu 
overpressure above an intake manifold. As a result, injector inlet pressure changes during operation. Additionally, there are control errors during gas pressure control that come from significant engine dynamics and evaporation system (LPG systems) inertia and a pressure control (in LPG and CNG systems.) This variation affects an injector mass flow characteristics, changing not only its slope (i.e. unit mass flow), but also the intersection point of this characteristics with a time axis.

This paper examines how the changes in input pressure influence a gas injector characteristics.

\section{Test stand and research object}

\subsection{Test stand}

The research was conducted on the test stand, as shown in Fig. 1. This test stand consists of an air handling system, comprising a piston compressor, an air dryer and a membrane input pressure controller. This system brings air into an injector section where the tested injector and pressure measurement systems are mounted. The test stand enables to measure pressure before and after the injector.

The test stand is fitted with a control unit developed at the Lublin University of Technology that can control the injector with any frequency, injection signal time and a current time course. This enables to conduct various types of research on gas injectors.

The test stand was fitted with a measurement system by National Instruments NI CompactDAQ cDAQ-9178 and data acquisition cards NI 9215 that enable a simultaneous measurement of voltage signals with a frequency of $100 \mathrm{kHz}$. A current sensor Tektronix TCP305 with an amplifier TCPA300 was used to measure the current in the injector coil. The pressure before the injector (input pressure) was measured with a sensor MPX5700 of a measurement range from 0 to $0.7 \mathrm{MPa}$ of absolute pressure; whereas the pressure behind the injector was measured with a sensor MPX4250 of a measurement range from 0 to $0.25 \mathrm{MPa}$ of absolute pressure. The test stand had also an air flow meter SFE3 by FESTO. During the measurements, all the sensors were supplied with constant supply voltage by a laboratory feeder.

\subsection{Research object}

The research was carried out on the VALTEK injector rail (Fig. 2). The rail had got four injection sections (separate injectors) of a mandrel design. The electromagnetic coil of a resistance of $3 \Omega$ made the mandrel move, which enforced a pulse-width modulation control (PWM). The mass flow control was done by selecting an appropriate injection nozzle that is screwed into the rail body. The injection nozzle was $2.6 \mathrm{~mm}$ in diameter.

\section{Research objective and scope}

The test was to determine the effect of input pressure (pressure at the injector entrance) on its characteristics, defined as the relationship between supplied gas mass and control signal time. wtryskiwacza. Ma to bezpośredni wpływ na charakterystykę wydatku wtryskiwacza.

Jednocześnie większość układów wtrysku sekwencyjnego gazu pracuje z reduktorami, w których ciśnienie gazu ustawiane jest jako stała wartość nadciśnienia nad kolektorem dolotowym. Powoduje to zmianę ciśnienia zasilania wtryskiwacza w czasie pracy. Do tego dokładają się uchyby regulacji ciśnienia gazu wynikające z dużej dynamiki pracy silnika oraz bezwładności układu odparowania (układy LPG) i regulacji ciśnienia (układy LPG i CNG). Zmienność ta wpływa na charakterystykę wydatku wtryskiwacza, nie tylko zmieniając jej kąt nachylenia (czyli wydatek jednostkowy), ale także punkt przecięcia tej charakterystyki z osią czasu.

Celem pracy jest zbadanie wpływu zmian ciśnienia zasilania na charakterystykę wtryskiwacza gazu.

\section{Stanowisko badawcze i obiekt badań}

\subsection{Stanowisko badawcze}

Badania zostały przeprowadzone na stanowisku badawczym, przedstawionym na rys. 1 . Stanowisko to składa się z układu przygotowania powietrza, obejmującego sprężarkę tłokową, osuszacz powietrza oraz membranowy regulator ciśnienia zasilania. Układ ten doprowadza powietrze do sekcji wtryskiwaczowej, w której zamocowany jest badany wtryskiwacz oraz układy pomiaru ciśnienia. Stanowisko umożliwia pomiar ciśnienia przed i za wtryskiwaczem.

Stanowisko wyposażone jest w badawczą jednostkę sterującą opracowaną na Politechnice Lubelskiej pozwalającą

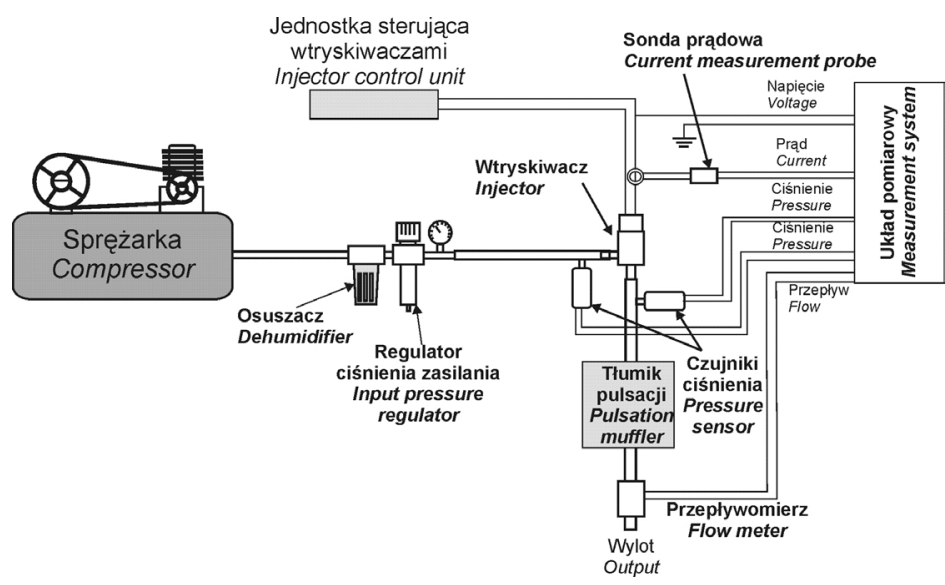

Fig. 1. Test stand

Rys. 1. Stanowisko badawcze

na sterowanie wtryskiwaczem z dowolną częstotliwością, długością trwania impulsu wtrysku oraz przebiegiem prądu. Pozwala to na przeprowadzenie szerokiego wachlarzu badań wtryskiwaczy gazowych.

Stanowisko wyposażono w układ pomiarowy firmy National Instruments NI CompactDAQ cDAQ-9178 wraz z kartami pomiarowymi NI 9215, umożliwiającymi pomiar symultaniczny sygnałów napięciowych z częstotliwością do $100 \mathrm{kHz}$. Do pomiaru prądu w cewce wtryskiwacza zastosowano sondę prądową Tektronix TCP305 wraz ze wzmacniaczem TCPA300. Do pomiary ciśnienia przed 


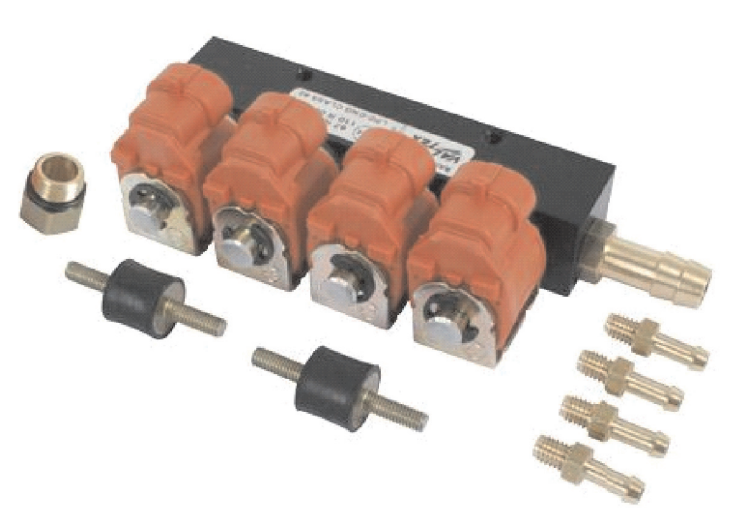

Fig. 2. Object of the research - injector rail VALTEK Rys. 2. Obiekt badań-listwa wtryskowa VALTEK

The research was conducted in steady states at controlled constant input pressure, specified frequency and control signal time. The input pressure was controlled according to the indications of a manometer and an additional sensor, mounted before the injector. This pressure was respectively $160,180,200,220$ and $250 \mathrm{kPa}$ of absolute pressure. The control of injector opening was during injector opening time from 2.5 to $12 \mathrm{~ms}$ and a continuous control signal was up to $3.0 \mathrm{~ms}$, and then the control was done using a rectangular signal of a frequency of $10 \mathrm{kHz}$ and an induction of $40 \%$. The injection frequency was $13.3 \mathrm{~Hz}$ (which corresponds with a sequential supply for a speed of $1600 \mathrm{rpm}$ ).

Quick-changing values (control signal, current in the coil, pressure before and after the injector) were measured in each measurement point using the measurement system described in chapter 2 at a sampling rate frequency of $50 \mathrm{kHz}$. Between 600 and 700 consecutive injections were recorded. An air mass flow rate was measured as an air stream and then converted into the mass flow in a single injection. The injector was supplied with air during the tests.

\section{Research results}

The results were analyzed with the software, developed by the author, in the LabView 8.2 environment. For each operation point (defined as input pressure and control signal time), the mean time course of the successive cycles (an exemplary time course is in Fig. 3) was worked out and the subsequent cycles were analyzed with respect to:

a) control signal time ( $t_{-} w t r$ imp $)$ - using a control signal; b) real injection opening time $\left(t_{-} w t r \_r\right)$ - using a signal from the pressure sensor (beginning of a pressure increase was assumed to be an injection start, and beginning of a pressure decrease, its end - Fig. 4);

c) injector opening lag time ( $\left.t \_o p\right)$ - using the analysis of a pressure signal and a control signal as an injection start lag from a control signal start.

Later on, based on all the subsequent cycles, such defined values were averaged. Simultaneously, real input pressure was defined as the mean value of an input pressure time course. It was respectively: 169, 194, 208, 231 and $259 \mathrm{kPa}$. This difference was due to a gauge error that indicated how pressure was controlled. wtryskiwaczem (ciśnienia zasilania) zastosowano czujnik MPX5700 o zakresie pomiarowym od 0 do 0,7 MPa ciśnienia bezwzględnego. Do pomiaru ciśnienia za wtryskiwaczem zastosowano czujnik MPX4250 o zakresie pomiarowym od 0 do $0,25 \mathrm{MPa}$ ciśnienia bezwzględnego. Stanowisko wyposażone było także w przepływomierze powietrza firmy FESTO serii SFE3. Wszystkie czujniki zasilane były z zasilacza laboratoryjnego utrzymującego stałe napięcie zasilania w czasie pomiarów.

\subsection{Obiekt badań}

Badania przeprowadzono na listwie wtryskowej firmy VALTEK (rys. 2). Listwa ta zawiera cztery sekcję wtryskowe (oddzielne wtryskiwacze) o konstrukcji trzpieniowej. Ruch trzpienia wywoływany jest cewką elektromagnetyczną o rezystancji $3 \Omega$, co wymusza sterowane z podtrzymaniem prądowym. Regulacja wydatku odbywa się poprzez dobór odpowiedniej dyszy wtryskowej wkręcanej w korpus szyny. Badania przeprowadzono na dyszy wtryskowej o średnicy $2,6 \mathrm{~mm}$.

\section{Cel i zakres badań}

Celem badań było określenie wpływu ciśnienia zasilania (ciśnienia na wejściu do wtryskiwacza) na jego charakterystykę, rozumianą jako zależność masy podawanego gazu od czasu trwania impulsu sterującego.

Badania prowadzono w stanach ustalonych przy stałym regulowanym ciśnieniu zasilania, określonej częstotliwości i długości trwania sygnału sterującego. Ciśnienie zasilania regulowano na podstawie wskazań manometru oraz dodatkowego czujnika umieszczonego przed wtryskiwaczem i wynosiło ono odpowiednio: 160, 180, 200, 220 i $250 \mathrm{kPa}$ ciśnienia bezwzględnego. Sterowanie otwarciem wtryskiwacza obejmowało zakres czasu otwarcia od 2,5 do $12 \mathrm{~ms}$, przy czym impuls ciągły sterowania wynosiła maksymalnie 3,0 ms a następnie sterowanie odbywało się z wykorzystaniem sygnału prostokątnego o częstotliwości $10 \mathrm{kHz}$ i wypełnieniu 40\%. Częstotliwość wtrysku wynosiła 13,3 $\mathrm{Hz}$ (co dopowiada zasilaniu sekwencyjnym przy prędkości obrotowej $1600 \mathrm{obr} / \mathrm{min})$.

W każdym punkcie pomiarowym mierzono wartości szybkozmienne (sygnał sterujący, prąd w cewce, cieśninie przed i za wtryskiwaczem) za pomocą układu pomiarowego opisanego w rozdziale $2 \mathrm{z}$ częstotliwością próbkowania wynoszącą $50 \mathrm{kHz}$. Zapis obejmował od 600 do 700 kolejnych wtrysków. Wydatek powietrza mierzono jako strumień powietrza i następnie przeliczono na wydatek masowy w czasie jednego wtrysku. Badania przeprowadzono zasilając wtryskiwacz powietrzem.

\section{Wyniki badań}

Analizę wyników badań przeprowadzono z wykorzystaniem opracowanego przez autora oprogramowania w środowisku LabView 8.2. W każdym punkcie pracy (określonym jako ciśnienie zasilania i czas trwania impulsu sterującego) analiza obejmowała opracowanie uśrednionego przebiegu $\mathrm{z}$ kolejnych, zarejestrowanych cykli (przykładowy przebieg przestawiono na rys. 3) oraz analizy kolejnych cykli pod kątem: 


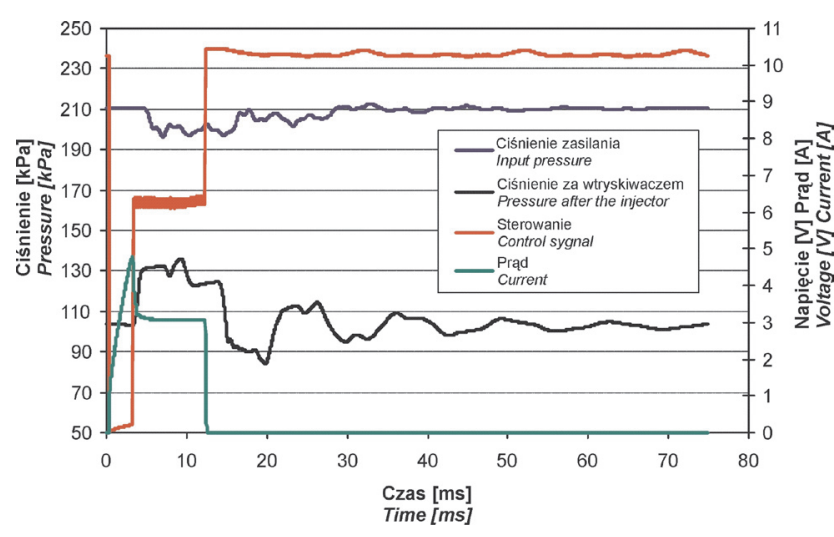

Fig. 3. Mean time course of measured values (input pressure $250 \mathrm{kPa}$, injection time $12 \mathrm{~ms}$ )

Rys. 3. Przebieg uśredniony mierzonych sygnałów (ciśnienie zasilania $250 \mathrm{kPa}$, czas wtrysku $12 \mathrm{~ms}$ )

The mean values were analyzed.

For each operation point, the dose of the injected fuel (air) during a single injection was specified after analyzing the signal of the air flow meter that was mounted at the end of the measurement system.

Then, the injector mass flow characteristics was made for each value of the input pressure (Fig. 5). It is as a relationship between an input mass in one injection $\left(m \_w t r\right)$ given in $\mathrm{mg}$ and injection time $\left(t \_w t r\right)$ as a control signal time given in $\mathrm{ms}$. Simultaneously, the analysis of quick-changing values helped develop the characteristics that shows how injection real time $(t$ wtr $r)$ depends on control signal time $\left(t_{-} w t r\right.$ imp $)$ - Fig. 6 . The analysis indicated that the characteristics became linear only after $6 \mathrm{~ms}$ of control signal time. Therefore, the analysis of an unit mass flow (coefficient of a characteristics gradient) and the intersection point of the characteristics with an $\mathrm{X}$ axis was done for the range of 6 to $12 \mathrm{~ms}$.

Figures 5 and 6 present the results of the approximation of a linear function. In each case, a very high match rate exceeding 0.98 was obtained. The further analysis (for the injector mass flow characteristics) included the slope

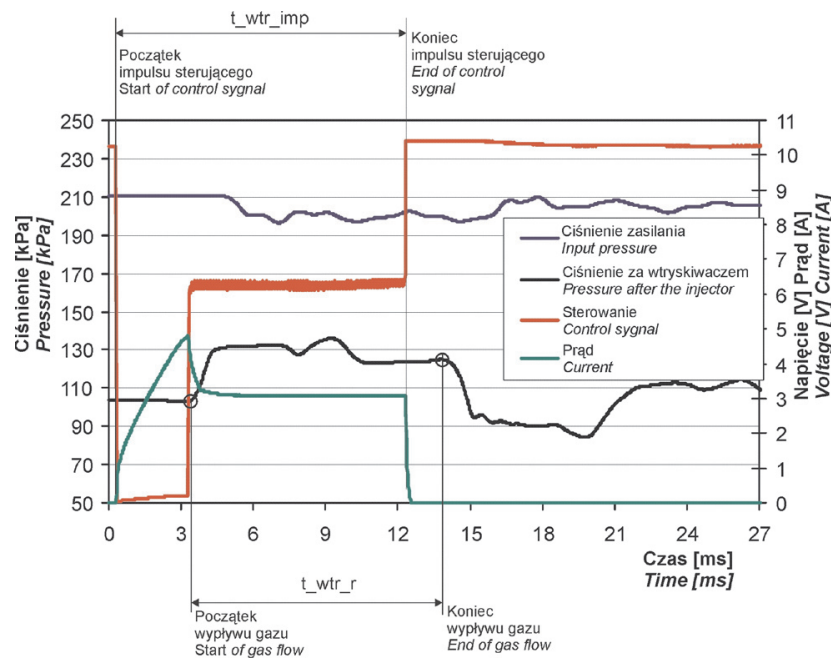

a) czasu trwania impulsu sterującego $\left(t_{-} w t r \_i m p\right)$ - na podstawie sygnału sterowania;

b) rzeczywistego czasu trwania wtrysku $\left(t_{-} w t r \_r\right)$ - na podstawie sygnału z czujnika ciśnienia (za początek wtrysku przyjęto początek wzrostu ciśnienia za wtryskiwaczem a jako koniec przyjęto początek spadku ciśnienia - rys. 4);

c) czasu opóźnienia otwarcia wtryskiwacza $\left(t \_o p\right)$ - na podstawie analizy sygnału ciśnienia i impulsu sterującego, jako opóźnienie początku wtrysku od początku impulsu sterującego.

Tak określone wartości były następnie uśredniane ze wszystkich kolejnych cykli. Jednocześnie określono rzeczywiste ciśnienie zasilania jako średnią wartość przebiegu ciśnienia zasilającego. Wynosiło ono odpowiednio: 169, 194, 208, 231 i 259 kPa. Różnica ta wynikała z błędu wskazań manometru zastosowanego jako wskaźnik regulacji ciśnienia.

Analizie poddano wartości średnie.

W każdym punkcie pracy określono także dawkę paliwa (powietrza) wtryskiwaną w czasie pojedynczego wtrysku. Określono to na podstawie analizy sygnału przepływomierza powietrza umieszczonego na końcu układu pomiarowego.

Następnie dla każdego ciśnienia zasilania sporządzono charakterystykę wydatku wtryskiwacza (rys. 5). Przedstawiono ją jako zależność masy podanej w jednym wtrysku ( $m$ _wtr) wyrażonej w mg od czasu wtrysku $\left(t \_w t r\right)$ rozumianego jako czas impulsu sterującego wyrażonego w ms. Jednocześnie na podstawie analizy wartości szybkozmiennych opracowano charakterystykę zależności rzeczywistego czasu trwania wtrysku ( $\left.t_{-} w t r \_r\right)$ od czasu trwania impulsu sterującego (t_wtr_imp) - rys. $\overline{6}$. Analizując opracowane charakterystyki zauważono, że liniowość uzyskują one dopiero po czasie trwania impulsu $6 \mathrm{~ms}$. Dlatego też analizę wydatku jednostkowego (współczynnika pochylenia charakterystyki) oraz punktu przecięcia charakterystyki z osią X przeprowadzono dla zakresu od 6 do $12 \mathrm{~ms}$.

Na rysunkach 5 i 6 przedstawiono wyniki aproksymacji funkcją liniową, w każdym przypadku otrzymując bardzo wysoki współczynnik dopasowania przekraczający 0,98 . Dalszej analizie poddano (w przypadku charakterystyki

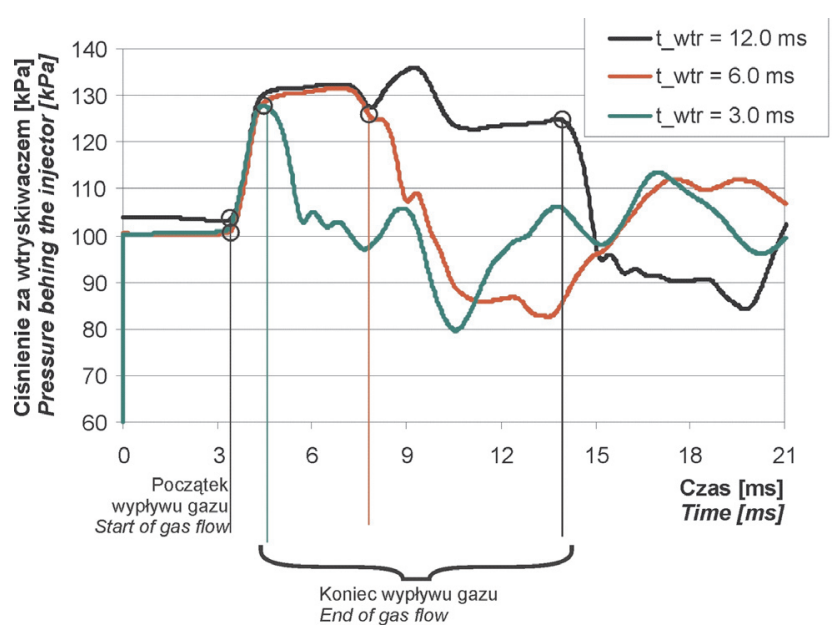

Fig. 4. Method of definitions of control signal time $\left(t_{-} w t r \_i m p\right)$ and real injection opening time $\left(t_{-} w t r_{-} r\right)$ - input pressure $250 \mathrm{kPa}$ Rys. 4. Sposób określania czasu impulsu sterujacego ( $t$ _wtr_imp) i czasu rzeczywistego otwarcia wtryskiwacza (t_wtr_r) - ciśnienie zasilania 250 kPa 

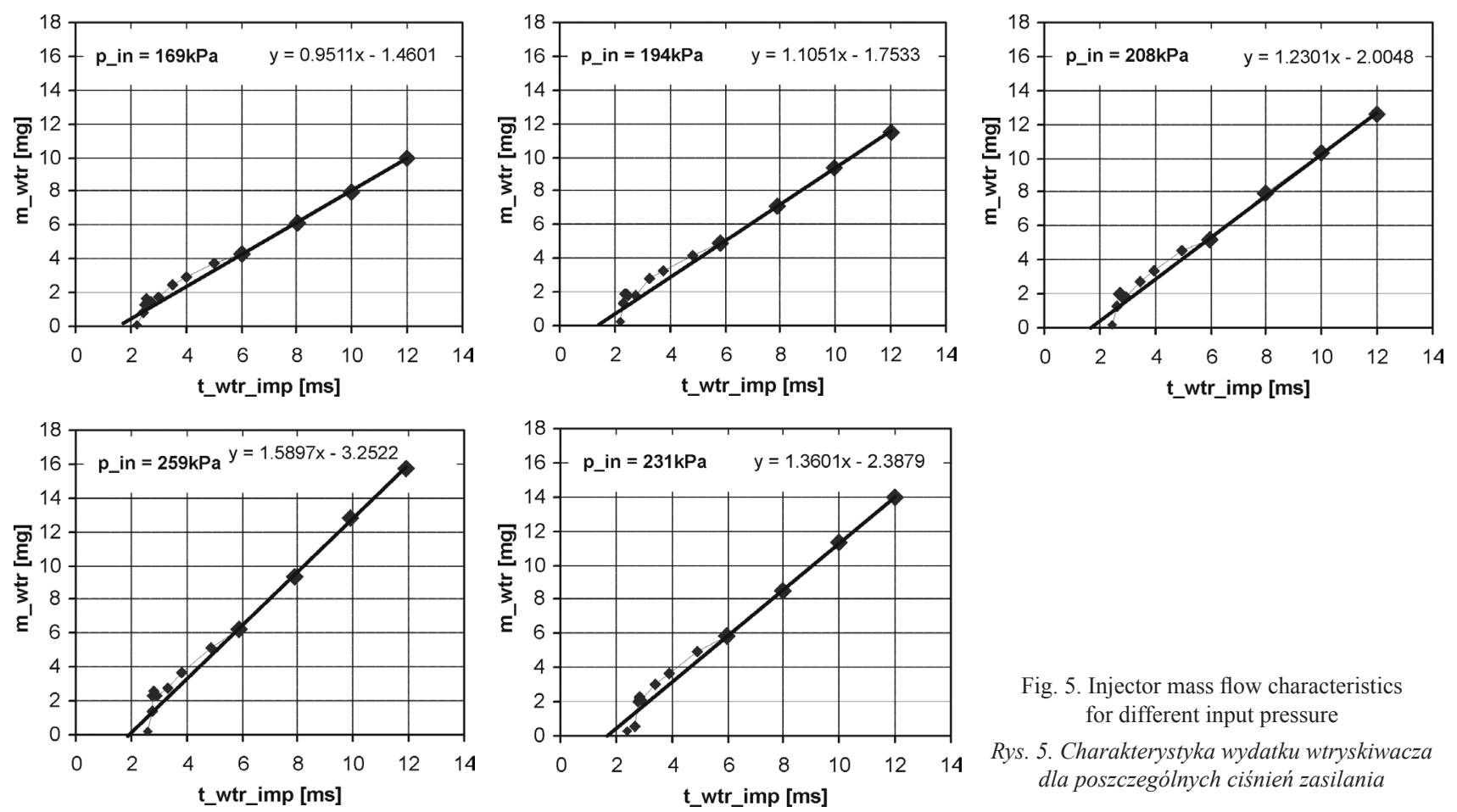

Fig. 5. Injector mass flow characteristics for different input pressure

Rys. 5. Charakterystyka wydatku wtryskiwacza dla poszczególnych ciśnień zasilania
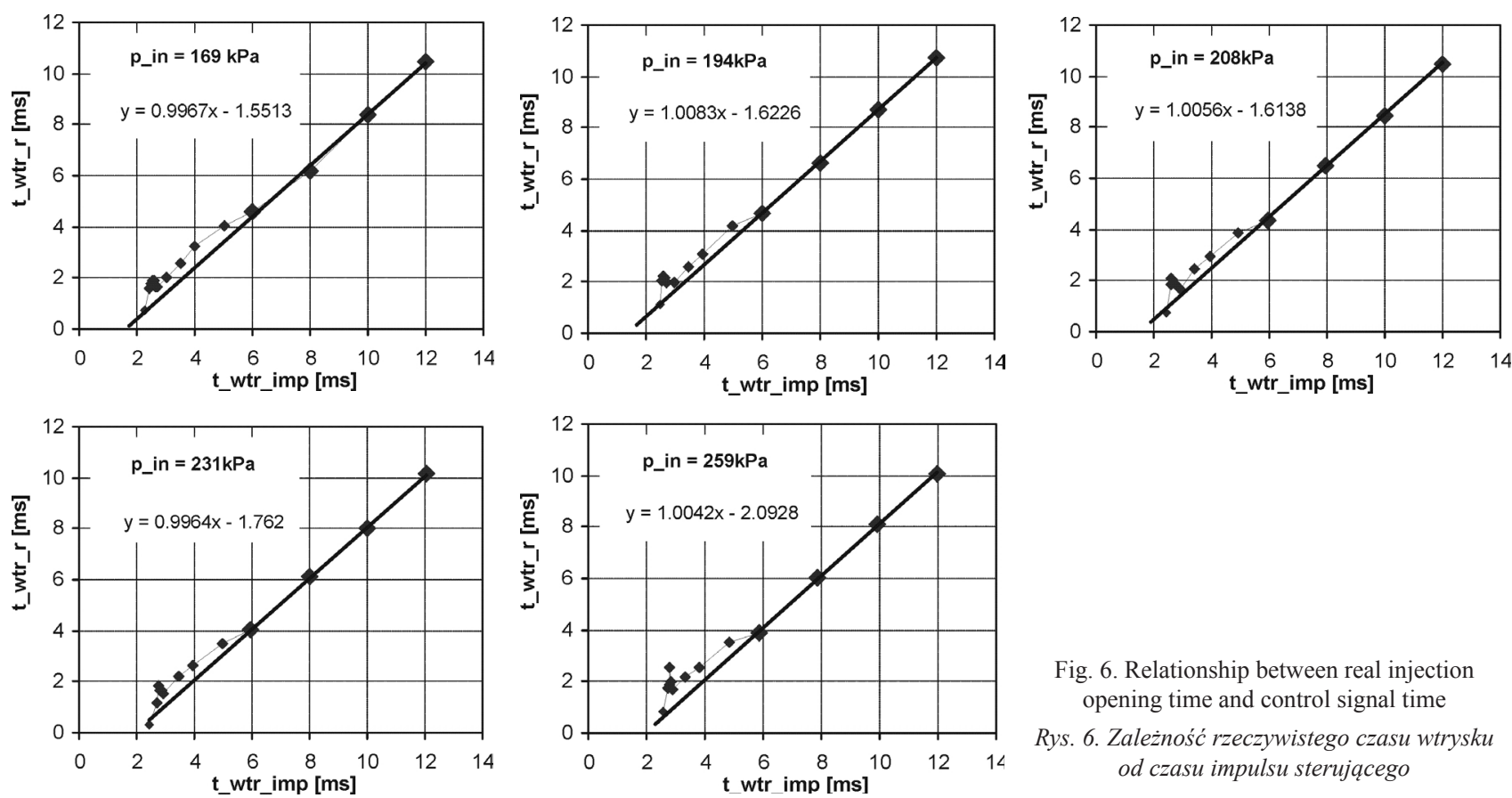

Fig. 6. Relationship between real injection opening time and control signal time

Rys. 6. Zależność rzeczywistego czasu wtrysku od czasu impulsu sterującego

coefficient of a straight line a and the intersection point of this straight line with an $\mathrm{X}$ axis - hereinafter designated as $t_{-} O-$ zero time. For the relationship between real time and signal control time, the analysis covered only the intersection point of a straight line with an $\mathrm{X}$ axis - hereinafter designated as $t \_0$.

Injector zero-time $t \_0$ was determined as follows:

$$
\mathrm{t}_{-} 0=-\frac{\mathrm{b}}{\mathrm{a}}
$$

where $a$ and $b$ are the coefficients of the equation of a straight line: $y=a \cdot x+b$. wydatku wtryskiwacza) współczynnik nachylenia prostej a oraz punkt przecięcia prostej z osią $\mathrm{X}$ - oznaczany dalej jako t_O - czas zerowy. W przypadku zależności czasu rzeczywistego od czasu impulsu przeanalizowano jedynie punkt przecięcia prostej z osią $\mathrm{X}$ - oznaczany dalej jako $t_{-} 0$.

Czas zerowy t_0 wyznaczano jako (1), gdzie: a i b - współczynniki równania prostej: $\mathrm{y}=\mathrm{a} \cdot \mathrm{x}+\mathrm{b}$.

W czasie każdej serii pomiarowej na zakładanym ciśnieniu zasilania określono także minimalny czasu otwarcia wtryskiwacza - tzw. martwy czas otwarcia wtryskiwacza t_pocz jako najkrótszy czas trwania impulsu sterującego po którym następuje otwarcie wtryskiwacza. Określono także 
In each measurement series for the assumed input pressure, the minimum injector opening time, the so-called injector opening dead time $t$ pocz, was defined as the shortest control signal time followed by injector opening. Also, injector opening lag time was defined as the time between a control signal start and a gas flow start.

\section{Analysis of the results}

Figure 7 shows how injector opening dead time $t$ pocz depends on input pressure. It is noted that as the pressure increases, the injector opening dead time increases linearly. This is due to increasing an injector anti-opening force that linearly depends on the pressure this electromagnetic coil needs to overcome. The increase in pressure requires more energy that is stored in the coil, which leads to increasing magnetic forces that influence the injector valve pivot. This is also apparent in injector opening lag time $t \_o p$ (Fig. 8). The increase in pressure causes a linear lag time increase (its slope corresponds with the change of injector opening dead time).

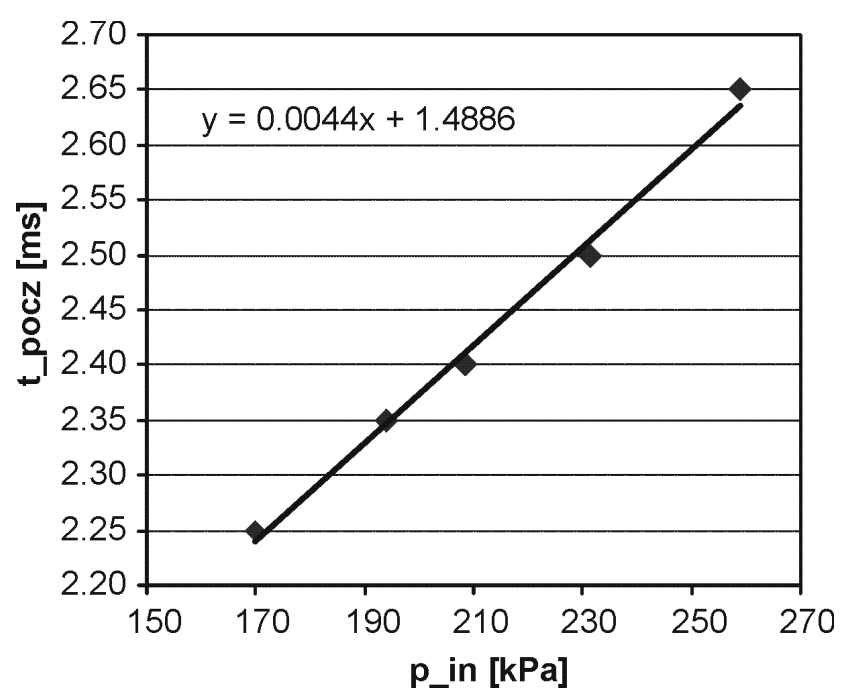

Fig. 7. Relationship between injection opening death time and input pressure

Rys. 7. Zależność martwego czasu otwarcia wtryskiwacza od ciśnienia zasilania

Figure 9 presents the relationship between an injector unit mass flow a (injector straight-line slope coefficient) and input pressure. This value is linearly dependent on input pressure, which is consistent with the theory of compressible fluid (gases) mechanics saying that, after reaching a critical flow speed, the value of injection flow mass depends linearly on input pressure as in the formula:

$$
\dot{\mathrm{m}}_{\text {przep }}=\mu_{\mathrm{p}} \cdot \mathrm{F}_{\text {przep }} \cdot \frac{\mathrm{p}_{\mathrm{o}}}{\sqrt{\mathrm{R} \cdot \mathrm{T}_{\mathrm{o}}}} \cdot \psi
$$

where: $\mu_{\mathrm{p}}$ - flow ratio, $\mathrm{F}_{\text {przep }}-\mathrm{a}$ valve mass flow surface, $\mathrm{p}_{\mathrm{o}}$ - input pressure, $\mathrm{T}_{\mathrm{o}}$ - input temperature, $\mathrm{R}$ - gas constant of a flowing gas, $\psi-$ a flow type coefficient.

Therefore, it can be concluded that for the tested input czas opóźnienia otwarcia wtryskiwacza, rozumiany jako czas pomiędzy początkiem sygnału sterującego a początkiem wypływu gazu.

\section{Analiza wyników badań}

Na rysunku 7 przedstawiono zależność czasu martwego czasu otwarcia wtryskiwacza $t$ pocz od ciśnienia zasilania. Jak można zauważyć wraz ze wzrostem ciśnienia rośnie liniowo martwy czasu otwarcia wtryskiwacza. Wynika to ze wzrostu siły przeciwdziałającej otwarciu wtryskiwacza, zależnej liniowo od ciśnienia, jaką musi pokonać cewka elektromagnetyczna. Wzrost ciśnienia wymaga zwiększenie ilości energii zgromadzonej w cewce, prowadzącej do wzrostu siły przyciągania trzpienia zaworu wtryskiwacza. Widoczne jest to także w czasie opóźnienia otwarcia wtryskiwacza $t \_o p$ (rys. 8). Wzrost ciśnienia powoduje liniowy wzrost tego opóźnienia (o nachyleniu zgodnym ze zmianą martwego czasu otwarcia wtryskiwacza).

Rysunek 9 przestawia zależność jednostkowego wydatku wtryskiwacza a (współczynnika nachylenia prostej

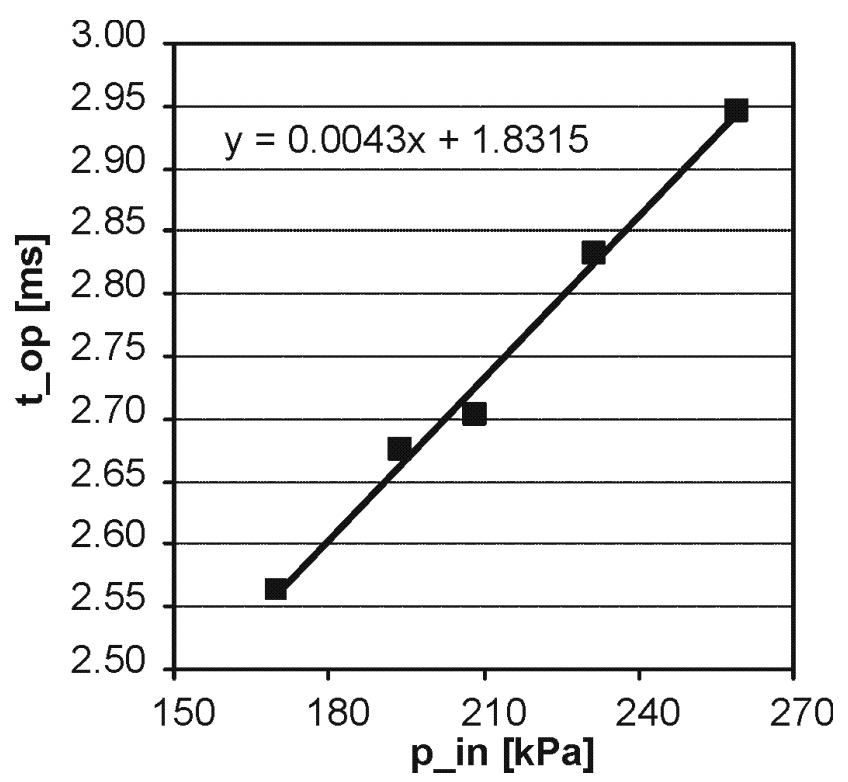

Fig. 8. Relationship between injection opening delay time and input pressure

Rys. 8. Zależność czasu opóźnienia otwarcia wtryskiwacza od ciśnienia zasilania

charakterystyki wtryskiwacza) od ciśnienia zasilania. Wartość ta jest liniowo zależna od ciśnienia, co jest zgodne z teorią przepływów płynów ściśliwych (gazów) mówiącej, że po osiągnięciu prędkości krytycznej przepływu wartość wydatku zależy liniowo od ciśnienia zasilania zgodnie ze wzorem (2),

gdzie: $\mu_{\mathrm{p}}$ - współczynnik przepływu przez przepustnicę, $\mathrm{F}_{\text {przep }}$ - powierzchnia przepływu przez przepustnicę, $\mathrm{p}_{\mathrm{o}}$ ciśnienie zasilania, $\mathrm{T}_{\mathrm{o}}$ - temperatura zasilania, $\mathrm{R}$ - stała gazowa przepływającego gazu, $\psi$ - współczynnik rodzaju przepływu.

Zatem można uznać, że w przypadku analizowanych ciśnień zasilania oraz danej konstrukcji wtryskiwacza mamy do czynienia z przepływem krytycznym przez zawór (lub 
pressure and the injector contracture, there is a critical mass flow through the injector valve (or reducer). The analysis so far cannot help specify the section that controls the flow so a further analysis is necessary, using for example the CFD method (as showed in $[1,7]$ ). zwężkę) wtryskiwacza. Na podstawie przeprowadzonych analiz nie można określić przekroju regulującego przepływ - konieczne jest przeprowadzenie dodatkowych analiz, przykładowo z wykorzystaniem metody CFD (jak pokazano w pracach $[1,7])$.

Wzrost ciśnienia powoduje także wzrost zero-

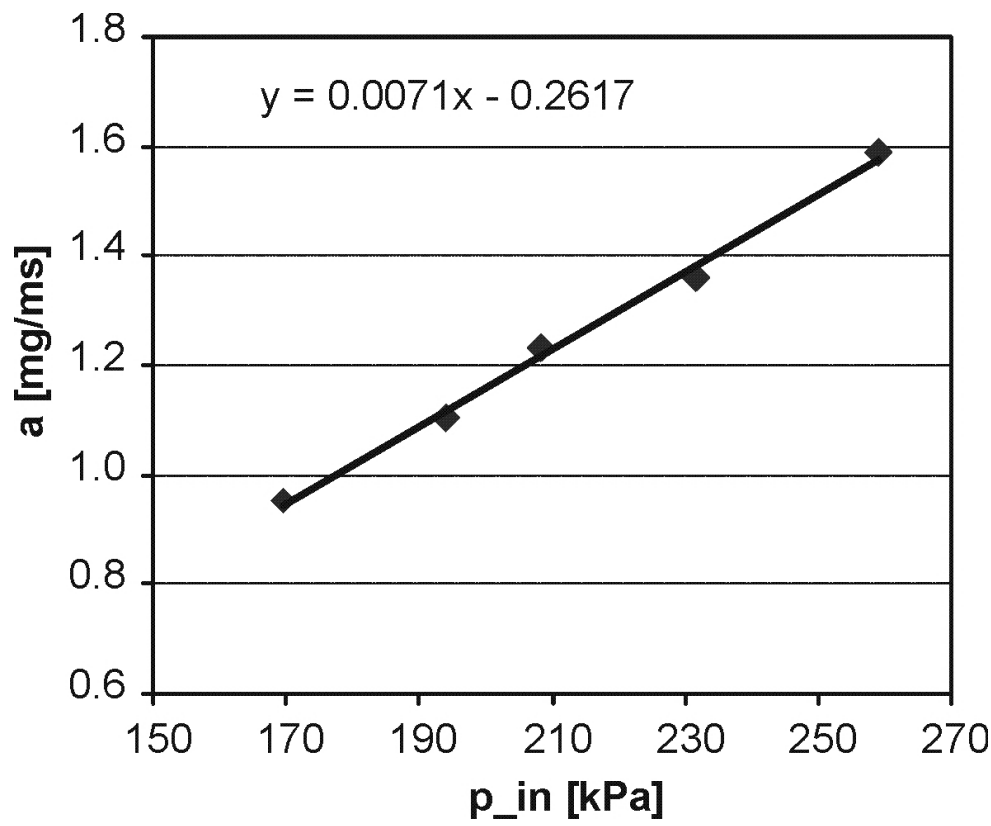

Fig. 9. Relationship between injection flow rate and input pressure Rys. 9. Zależność jednostkowego wydatku wtryskiwacza od ciśnienia zasilania wego czasu wtrysku (przecięcia charakterystyki $\mathrm{z}$ osią $\mathrm{X}$ ) - rys. 10. Wzrost ten nie jest jednak liniowy. Na rysunku 10 przedstawiono zerowy czas wtrysku wyznaczony zarówno z charakterystyki wydatku wtryskiwacza (linia przerywana) jak też z zależności czasu rzeczywistego otwarcia wtryskiwacza od czasu trwania impulsu wtryskowego (linia ciągła). W obu przypadkach wartości te praktycznie się pokrywają. Oznacza to, że różnica pomiędzy czasem rzeczywistym a impulsem sterującym bezpośrednio wpływa na kształt charakterystyki wydatku wtryskiwacza. Wzrost ciśnienia powoduje zwiększenie różnicy miedzy czasem rzeczywistym i impulsem sterującym a więc skrócenie rzeczywistego czasu otwarcia wtryskiwacza. Oznacza to, że przy jednoczesnym wzroście czasu opóźnienia otwarcia wtryskiwacza (rys. 8) następuje skrócenie czasu opóźnienia jego zamknięcia.

\section{Dyskusja}

Analizując charakterystyki przedstawione na rys. 5 i 6 można zauważyć, że nie są one liniowe w całym zakresie. Wyraźnie widoczne jest „wy-

As the pressure increases, injection zero time (intersection point of the characteristics with an $\mathrm{X}$ axis) increases as well, as seen in Fig. 10. This increase, however, is not linear. Injection zero time was determined by the injector mass flow characteristics (dotted line) as well as by the relationship between injector opening real time and injection signal time (solid line), which is given in Fig. 10. These values practically coincide in both cases. This means that the difference between real time and a control signal directly influences the injector mass flow characteristics. The increase in pressure increases the difference between real time and a control signal, and thus reduces injector opening real time. This means that the increase in injector opening lag time (Fig. 8) is simultaneously accompanied by reduced injector closing lag time.

\section{Discussion}

Based on the characteristics in Figs 4 and 5, it can be noted that they are not linear throughout their all ranges. It is easy to see the "bulge" in the initial part of the characteristics. This is evident both for a fuel dosage and the difference between real opening time and a control signal. Therefore, the question arises about what causes this phenomenon.

The four different areas of injection characteristics are marked in Fig. 11. The same areas

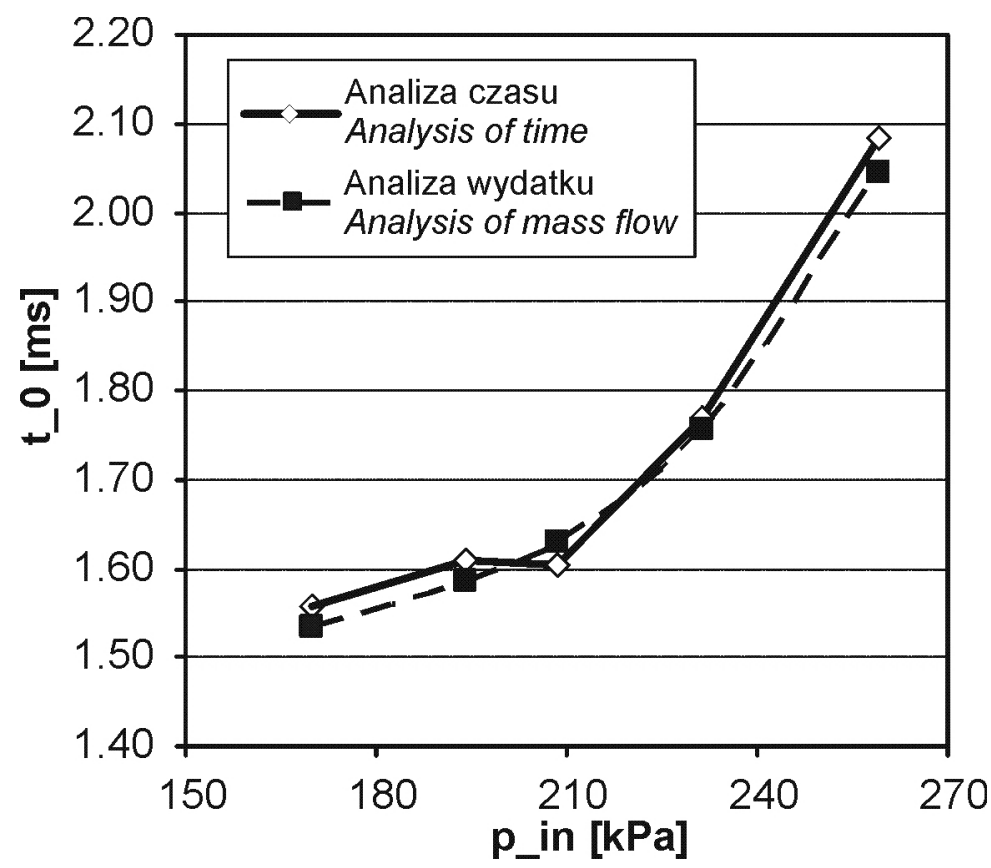

Fig. 10. Relationship between injection zero-time $t_{-} 0$ and input pressure Rys. 10. Zależność zerowego czasu wtrysku t_o od ciśnienia zasilania 


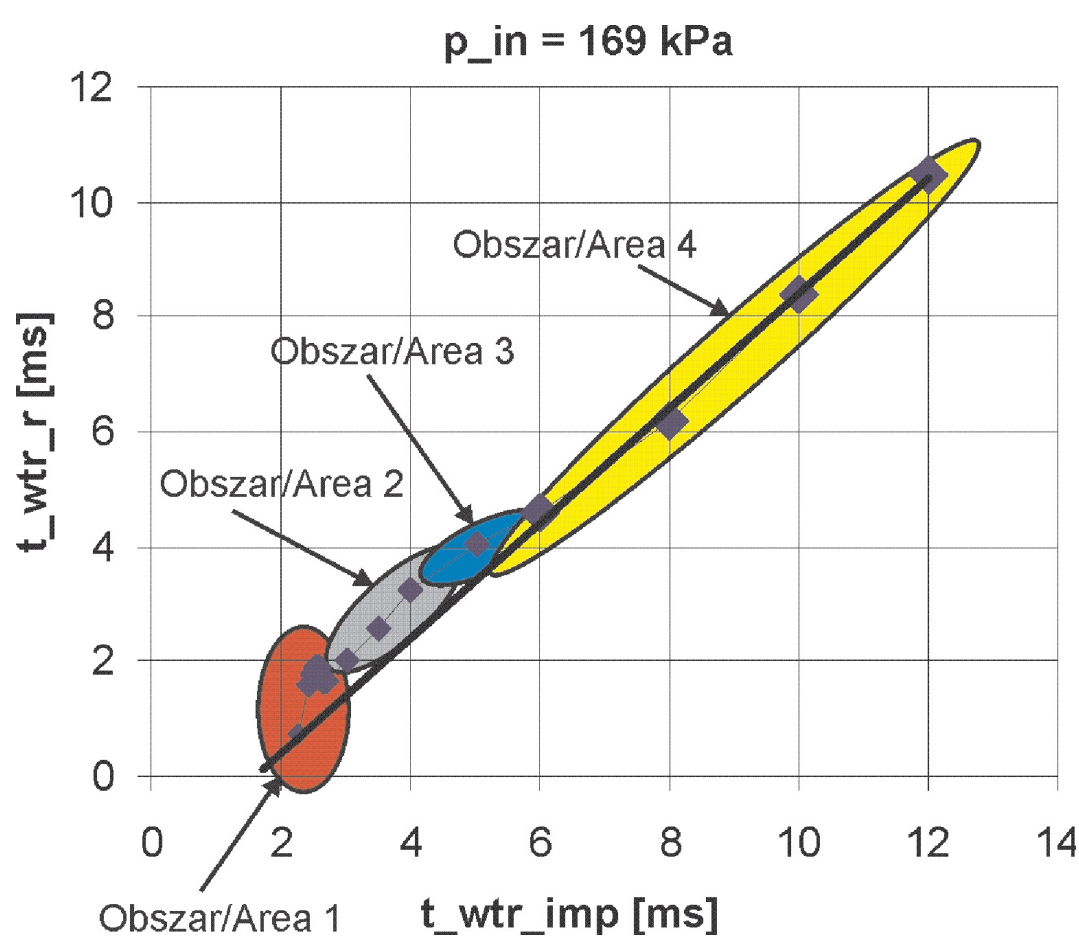

Fig. 11. Areas of injection characteristic Rys. 11. Obszary charakterystyki wtryskiwacza

can be marked on both the injector mass flow characteristics and the relationship between opening real time and control signal time (Fig. 11). These areas can be describes as follows:

Area 1: Area of "starting" - it covers the range of control signal times that are near injector opening dead time. The area covers injector half-opening and gas flow stabilization time and its settling. In the first part, injector mass flow changes rapidly, even after control signal time is changed minimally, which indicates that the flow area has changed (and thus the pivot valve lift has changed). Later, there is the period of gas flow stabilization according to the phenomena described in $[1,7]$;

Area 2: Area of stable operation at a full current - here the injector characteristics becomes even but at a higher level than a basic characteristics;

Area 3: Area of transition;

Area 4: Area of stable operation at a limited current.

The major difference between areas 2 and 4 is the amount of energy stored in the coil. Changing a control method based on a full current (continuous coil supply) into a current uphold (the coil is powered by an alternating pulse-width modulated power signal) - Fig. 12 - changes the amount of energy stored in the coil at the end of a control signal. This results in shorter injector closing lag
Na rysunku 11 zaznaczono 4 różniące się od siebie obszary charakterystyki. Identyczne obszary można wyznaczyć zarówno na charakterystyce wydatku wtryskiwacza jak i na zależności miedzy czasem rzeczywistego otwarcia a czasem impulsu sterującego (rys. 11). Obszary te można oznaczyć jako:

Obszar 1: Obszar „rozruchowy” - obejmuje on zakresu czasów impulsu sterującego bliskich martwemu czasowi otwarcia wtryskiwacza. Obszar ten obejmuje zakres niepełnego otwarcia wtryskiwacza oraz okresu stabilizacji i ustalenia się przepływu gazu. W pierwszym zakresie tego obszaru następuje gwałtowna zmiana wydatku wtryskiwacza nawet po minimalnej zmianie czasu impulsu sterującego, co świadczy o tym, że zmieniło się pole przepływu (a zatem zmienił się wznios trzpienia zaworu).

14 W dalszej części następuje okres stabilizacji przepływu zgodnie ze zjawiskami opisanymi w pracach $[1,7]$.

Obszar 2: Obszar stabilnej pracy przy pełnym prądzie - w okresie tym następuje wyrównanie charakterystyki wtryskiwacza, ale na poziomie wyższym niż charakterystyka podstawowa.

Obszar 3: Obszar przejściowy

Obszar 4: Obszar stabilnej pracy przy ograniczonym prądzie

Podstawową różnicą miedzy obszarami 2 i 4 jest ilość energii zgromadzonej w cewce. Zmiana sposobu sterowania cewką z pełnego prądu (ciągłego zasilania cewki) na podtrzymanie prądowe (zasilanie cewki sygnałem zmiennym prostokątnym o stałym wypełnieniu) - rys. 12 - powoduje zmianę ilości energii zgromadzonej w cewce na końcu trwania impulsu sterującego. Powoduje to skrócenie czasu 
time in area 4 of the characteristics. This difference can be even $0.7 \mathrm{~ms}$.

Area 3 is a transition period between areas 2 and 4 . Here, the amount of energy stored in the coil and injector closure lag time change.

\section{Conclusions}

1. The increase in input pressure causes:

a) linear increase in an injector unit mass flow

b) linear increase in injection dead time

c) linear increase in injection lag time

d) non-linear increase in injection zero time, which follows decreasing injector closure lag time.

2. The change in injection dead time almost equals the change in injector opening lag time. This is due to the need to obtain more energy in the electromagnetic coil, and therefore a more significant force that would influence the valve mandrel.

3. Changing the powering method of the coil (control) changes injector closing lag time and injector operation characteristics.

Paper reviewed/Artykut recenzowany opóźnienia zamykania wtryskiwacza w obszarze 4 charakterystyki. Różnica ta wynosi nawet $0,7 \mathrm{~ms}$.

Obszar 3 stanowi natomiast okres przejściowy pomiędzy obszarami 2 i 4. W tym zakresie zmienia się ilość energii zgromadzonej w cewce i zmienia się też czas opóźnienia zamknięcia wtryskiwacza.

\section{Wnioski}

1. Wzrost ciśnienia zasilania powoduje:

a) liniowy wzrost wydatku wtryskiwacza,

b)liniowy wzrost martwego czasu wtrysku,

c) liniowy wzrost czasu opóźnienia wtrysku,

d)nieliniowy wzrost zerowego czasu wtrysku, co wynika ze spadku czasu opóźnienia zamknięcia wtryskiwacza.

2. Zmiana martwego czasu wtrysku jest prawie równa zmianie czasu opóźnienia otwarcia wtryskiwacza. Wynika to $\mathrm{z}$ konieczności uzyskania zwiększonej energii w cewce elektromagnetycznej, a zatem większej siły oddziałującej na trzpień zaworu.

3. Zmiana sposobu zasilania (sterowania) cewki zmienia czas opóźnienia zamknięcia wtryskiwacza zmieniając także charakterystykę jego pracy.

\section{Bibliography/Literatura}

[1] Czarnigowski J., Wendeker M., Jakliński P., Rola M., Grabowski Ł., Pietrykowski K.: FD model of fuel rail for LPG systems, SAE 2007-01-2053.

[2] Jakliński P., Czarnigowski J., Wendeker M.: The Effect of Injection Start Angle of Vaporized LPG on SI Engine Operation Parameters, SAE 2007-01-2054.

[3] Jakliński P., Grabowski Ł., Wendeker M., Czarnigowski J., Szczęsny P., Barański G., Sochaczewski R.: Analiza wpływu umieszczenia wtryskiwacza LPG na parametry pracy silnika o zapłonie iskrowym, PTNSS-2007-SS4-222, Silniki Spalinowe, nr 4/2007, s. 33-41.

[4] Lee S., Kuswaka J., Daisho Y.: Mixture Formation and Combustion Characteristics of Directly Injected LPG Spray, SAE Technical Paper 2003-01-1917.

[5] Małek A, Wendeker M., Czarnigowski J., Grabowski Ł., Jakliński P., Barański G., Sochaczewski R., Podleśny M.: Stanowisko do badań prehomologacyjnych dla pojazdów wyposażonych w układ sekwencyjnego wtrysku gazu LPG, PTNSS CONGRESS-2007 P07-C148, Silniki Spalinowe PTNSS-2007-SC2.
[6] Regulamin nr 83 Europejskiej Komisji Gospodarczej Organizacji Narodów Zjednoczonych (EKG ONZ) - Jednolite przepisy dotyczące homologacji pojazdów w zakresie emisji zanieczyszczeń w zależności od paliwa zasilającego silnik, Dziennik Urzędowy Unii Europejskiej L(legislacja) nr. 119 z 6.5.2008, str. $1-181$.

[7] Wendeker M., Jakliński P., Czarnigowski J., Rola M., Grabowski Ł., Pietrykowski K.: CFD model of fuel rail for LPG systems, SAE Technical Paper 2007-01-2053.

Mr. Jacek Czarnigowski, DEng. - doctor in the Faculty of Mechanical Engineering at Lublin University of Technology.

Dr inż. Jacek Czarnigowski - adiunkt na Wydziale Mechanicznym Politechniki Lubelskiej.

e-mail:j.czarnigowski@pollub.pl 